Sains Malaysiana 47(3)(2018): 581-587

http://dx.doi.org/10.17576/jsm-2018-4703-19

\title{
Sol-gel Synthesis and Optical Properties of Malayaite Ceramic Colour Pigments
}

\author{
(Sintesis Sol-gel dan Sifat Optik Pigmen Warna Seramik Malayait)
}

\author{
N. YONGVANICH*, N. WANGWANICH \& N. PHOMWANA
}

\section{ABSTRACT}

Ceramic colour pigments based on the malayaite structure was synthesized by sol-gel with an aim to obtain homogeneous powder systems. The formulation was $\mathrm{Ca}\left(\mathrm{Sn}_{1-x} \mathrm{Cr}_{x}\right) \mathrm{SiO}_{5}$ where $\mathrm{x}=0,0.02$ and 0.05. Thermogravimetric analysis and infrared spectroscopy suggested suitable calcination temperatures to be $>1000^{\circ} \mathrm{C}$. Formation of malayaite phase was found to be very difficult; high calcination temperatures up to $1400^{\circ} \mathrm{C}$ was required which was typical for this particular phase. Nevertheless, small amounts of impurities were still present and were found to be both wollastonite $\left(\mathrm{CaSiO}_{3}\right)$ and cassiterite $\left(\mathrm{SnO}_{2}\right)$. The oxidation state of chromium was found to be mainly $4+$. The obtained pigment particles were in the range of 1-5 micron with a high degree of agglomeration due to sintering. UV-vis spectra demonstrated broad absorbance peak in the 550-600 $\mathrm{nm}$ range which could be attributed to both $\mathrm{Cr}(\mathrm{III})$ and $\mathrm{Cr}(\mathrm{IV})$. The colour parameters in the CIELAb system showed a red tone (more positive $a^{*}$ values whereas $b^{*}$ remained relatively constant) when chromium was doped into the malayaite host. Preliminary interaction testing with a low-fire glaze displayed an even improvement in the $a^{*}$ parameter (getting more red tone). Microscopic studies showed a certain degree of chromium diffusion out of the pigment powders toward the glaze matrix. These results have demonstrated a great potential for this refractory colour pigments to be possibly utilized in other kinds of glazes as well.

Keywords: Ceramics; colour; malayaite; pigment; sol-gel

\section{ABSTRAK}

Pigmen warna seramik berdasarkan struktur malayait disintesis oleh sol-gel dengan matlamat untuk mendapatkan sistem serbuk homogen. Rumusannya ialah $\mathrm{Ca}\left(\mathrm{Sn}_{1-x} \mathrm{Cr}_{x}\right)$ SiO5 dengan $x=0,0.02$ dan 0.05. Analisis termogravimetri dan spektroskopi inframerah dicadangkan sesuai untuk pengkalsinan bagi suhu $>1000^{\circ} \mathrm{C}$. Pembentukan fasa malayait didapati sangat sukar; suhu kalsinasi yang tinggi sehingga $1400^{\circ} \mathrm{C}$ diperlukan secara tipikal pada fasa ini. Walau bagaimanapun, sejumlah kecil kekotoran masih ada dan didapati pada kedua-dua wolastonit (CaSiO $)_{3}$ dan kasiterit $\left(\mathrm{SnO}_{2}\right)$. Keadaan pengoksidaan kromium didapati 4+ terutamanya.Zarah pigmen yang diperoleh berada dalam lingkungan 1-5 mikron dengan aglomerasi yang tinggi kerana sinteran. Spektrum sinar UV menunjukkan puncak penyerapan luas dalam lingkungan 550-600 nm yang boleh dikaitkan dengan kedua-dua Cr(III) dan Cr(IV). Parameter warna dalam sistem CIELab menunjukkan nada merah (lebih nilai positif $a^{*}$ sedangkan $b^{*}$ kekal agak berterusan) apabila kromium terdop ke dalam perumah malayait. Ujian interaksi awal dengan api kecil memaparkan peningkatan yang lebih baik dalam parameter $a^{*}$ (mendapatkan lebih banyak nada merah). Kajian mikroskopik mendedahkan penyerapan darjah tertentu kromium daripada serbuk pigmen ke arah matriks glas. Keputusan ini telah menunjukkan potensi yang besar untuk pigmen warna refraktori ini yang mungkin digunakan dalam jenis glas lain juga.

Kata kunci: Malayait; pigmen; sol-gel; seramik; warna

\section{INTRODUCTION}

Malayaite colour pigments are one of several inorganic pigments currently employed in the ceramic industry. When doped with certain cationic chromophores, the pigments exhibits distinctive reddish and purplish colour tones which are quite unique among various colour stains. This phase was considered to be a rare variety and possesses a good thermal stability (Harisanov et al. 2003). It has a crystal structure of monoclinic system with infinite chains of corner-sharing $\mathrm{SnO}_{6}$ octahedra (Ou-benmmou et al. 2000; Pina et al. 2005). The structure itself could also accommodate several d-and f- elements, especially in the tin and calcium sites (Ou-benmmou et al. 2000), with only a few pink-tone pigments produced industrially (12-25-5 in the DCMA classification) (Harisanov et al. 2003). The malayaite phase is also an only alternative to cadmiumcontaining pigments yielding deep burgundy shades (Lee \& Lee 2009; Lopez-Navarrete et al. 2003).

The majority of ceramic pigments were usually synthesized by solid-state processing or ceramic method due to simplicity using oxides or carbonates. However, conventional solid-state processing could not usually yield desirable single phase due to low reactivity and high refractoriness of the starting oxide precursors. Intermediate grinding is usually required to increase homogeneity and enhance reactivity (Harisanov et al. 2003). Addition 
of mineralizers has been one way of enhancing phase formation but additional chemical species might affect the optical properties of the obtained pigments when incorporating in glazes. It is well-known that the solgel method offers high chemical homogeneity with the possibility of synthesis temperature reduction. In addition, such method is advantageous in term of molecular-level doping of cations in the crystal structure (Halefoglu \& Kusvuran 2010).

Although sol-gel is not as low cost and simple, the yielded results could probably by advantageous to the final glazed products due to better (more uniform) pigment particle distribution. In the study by Halefoglu and Kusvuran (2010), formation of malayaite occurred at as low as $1000^{\circ} \mathrm{C}$. However, secondary XRD peaks were still observed but were not indexed in the study. Infrared spectroscopy was employed by the authors to confirm occurrence of $\mathrm{Sn}-\mathrm{O}$ bonding in the malayaite structure. Although the authors reported dissolution of the pigments in the glaze, there was still doubt given an unclear SEM image. However, the processing itself was not as commonly employed for the synthesis of malayaite colour pigments. Thus, the objective of this study was to examine the processibility of malayaite phase by sol-gel and the possibility of improvement in the glazed products.

\section{MATERIALS AND METHODS}

Sol-gel synthesis of $\mathrm{Ca}\left(\mathrm{Sn}_{1-\mathrm{x}} \mathrm{Cr}_{\mathrm{x}}\right) \mathrm{SiO}_{5}$ where $\mathrm{x}=0,0.02$ and 0.05 have been carried out using reagent-grade chemicals $\left(\mathrm{Ca}\left(\mathrm{NO}_{3}\right)_{2} \cdot 4 \mathrm{H}_{2} \mathrm{O}, \mathrm{SnCl}_{4} \cdot 5 \mathrm{H}_{2} \mathrm{O}\right.$ and $\left.\mathrm{Cr}\left(\mathrm{NO}_{3}\right)_{3} \cdot 9 \mathrm{H}_{2} \mathrm{O}\right)$ in required stoichiometric amounts $\left(\mathrm{Ca}\left(\mathrm{Sn}_{1-\mathrm{x}} \mathrm{Cr}_{\mathrm{x}}\right) \mathrm{SiO}_{5}\right)$. The doping amount does not have to be high as chromium has high colouring power according to Faurel et al. (2003). The solvent system was composed of TEOS, isopropanol and distilled water in the 1:3:1 mole ratio. The precursors were dissolved and magnetically stirred for $2 \mathrm{~h}$. The gel mixture was dried at $120^{\circ} \mathrm{C}$ for $24 \mathrm{~h}$ and later calcined at different temperatures in air $\left(5^{\circ} \mathrm{C}\right.$ per $\left.\mathrm{min}\right)$. Various characterization techniques, including thermogravimetric analysis (TGA), Fourier transformed infrared spectroscopy (FTIR, KBr) and differential thermal analysis (DTA, in $\mathrm{O}_{2}$ ), have been used to examine the appropriate calcination temperature. The phasic nature was investigated by X-ray Diffraction (XRD, CuK $\alpha 1.5406 \AA$ ) whereas the successful doping was confirmed by both XRD and Raman spectroscopy (532 nm). $\mathrm{X}$-ray photoelectron spectroscopy (XPS) was employed to examine the oxidation state and stoichiometry. The morphology of the obtained particles was examined by scanning electron microscope (SEM). The optical properties were studied by UV-vis spectroscopy and the CIELab colour system.

\section{RESULTS AND DISCUSSION}

The appropriate calcining temperature for elimination of organic residues was determined by Thermogravimetric Analysis (TGA) shown in Figure 1. There were roughly three stages of decomposition; all could be attributed to water molecules and organic and inorganic residues. Beyond $800^{\circ} \mathrm{C}$, there was relatively no weight reduction. Therefore, calcination should be carried out at temperatures higher than $800^{\circ} \mathrm{C}$ for complete decomposition. Thermal behavior was further examined by differential thermal analysis (DTA) for showing different temperature ranges caused by different reactions characterized by endothermic and exothermic peaks. Broad endothermic peaks at temperature less than $200^{\circ} \mathrm{C}$ were likely associated with dehydroxylation of the precursors. There seemed to be a large peak at $>1100^{\circ} \mathrm{C}$, indicating a large change in thermal behavior (the limit of the DTA instrument used in this study was $1300^{\circ} \mathrm{C}$ ). This result was likely associated with phase formation of malayaite which has been widely known to be occurring at very high temperatures. Zhang et al. (2010) also reported an intense exothermic peak at $1065.6^{\circ} \mathrm{C}$ which was likely be related to crystallization or transformation process. From both TGA and DTA results, the gels were calcined at $\geq 1000^{\circ} \mathrm{C}$.
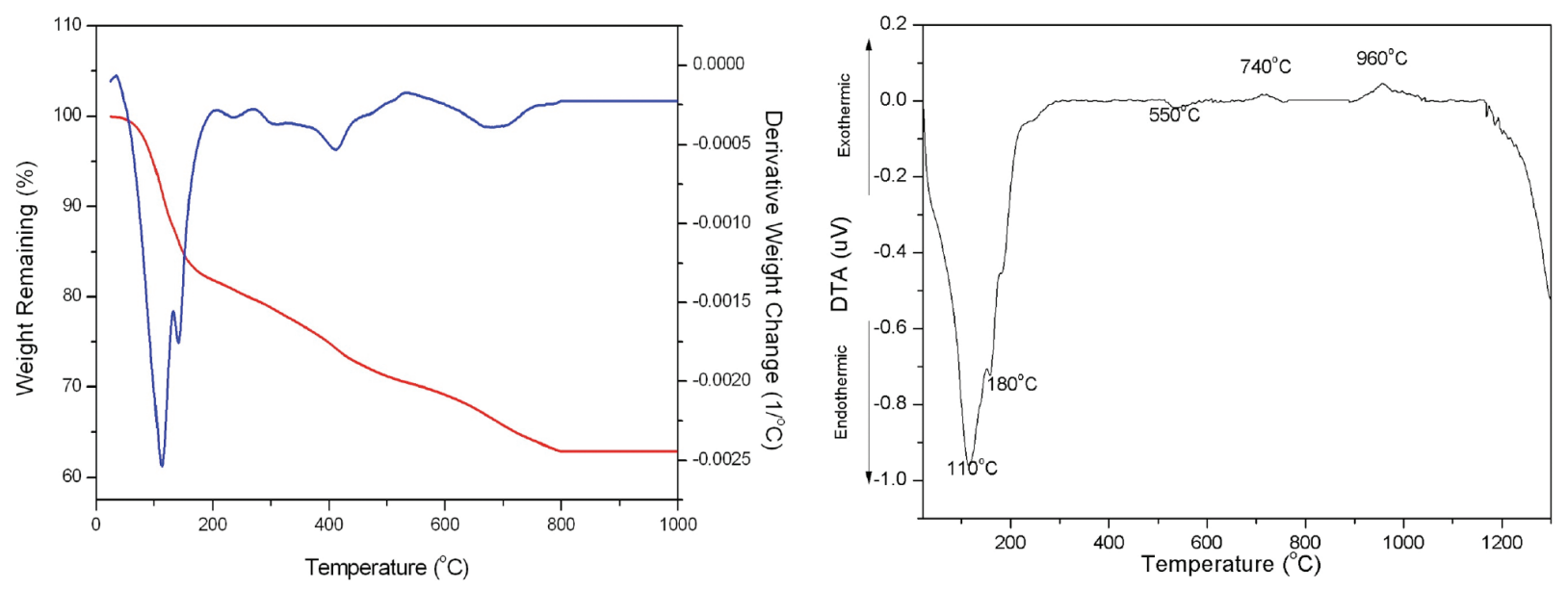

FIGURE 1. Thermal behavior of the uncalcined $x=0.05$ samples: Thermogravimetric analysis or TGA (left) and differential thermal analysis or DTA (right) 
Elimination of inorganic and organic residues was examined by Fourier transformed infrared spectroscopy (FTIR). The FTIR results (Figure 2) could confirm that organic and inorganic residues were completely eliminated upon calcination at $\geq 1000^{\circ} \mathrm{C}$. After calcinations, peaks associated with $\mathrm{OH}$ stretching and $\mathrm{Si}-\mathrm{O}$ quartz $\left(788 \mathrm{~cm}^{-1}\right)$ were almost completely disappeared. After firing, many new peaks emerged as expected from various bonding types in the malayaite structure and they were sharper with increasing calcinations temperature. The peaks in the $400-600 \mathrm{~cm}^{-1}$ range were believed to be of $\mathrm{Ca}-\mathrm{O}$, $\mathrm{Si}-\mathrm{O}$ and $\mathrm{Sn}-\mathrm{O}$ in the malayaite crystal structure. Lee and Lee (2008a) attributed four peaks (560, 675, 807 and $900 \mathrm{~cm}^{-1}$ ) to the malayaite phase, whereas Halefoglu and Kusvuran (2010) to the bands at 563, 905, 907 and $940 \mathrm{~cm}^{-1}$. Furthermore, when increasing from $1000^{\circ} \mathrm{C}$ to $1400^{\circ} \mathrm{C}$, obvious reduction in the peak intensity $(675$ and $716 \mathrm{~cm}^{-1}$ ) relative to those in the $800-1100 \mathrm{~cm}^{-1}$ range was observed. This result could be attributed to a decrease in the amount of $\mathrm{Si}-\mathrm{O}-\mathrm{Si}$ bending character commonly related to free $\mathrm{SiO}_{2}$. Therefore, very high temperatures were require for the synthesis as $\mathrm{SiO}_{2}$ itself is very refractory. Also, alterations in the peak position and shape could signify the possibility of malayaite phase crystallization as suggested earlier by DTA.

Incorporation of $\mathrm{Cr}$ ions into the malayaite lattice was quantitatively probed by Raman spectroscopy. The Raman spectra of the undoped and doped samples are shown in Figure 2 (right). Different vibration modes at 321,360 and $570 \mathrm{~cm}^{-1}$ belong to $\mathrm{Sn}-\mathrm{O}$ with different bond lengths in the malayaite structure. Dominant surges of the peaks at $>700$ $\mathrm{cm}^{-1}$ were likely associated with incorporation of $\mathrm{Cr}^{4+}$ in the lattice, inducing the red and purple tone of the pigments. Upon doping, there were obvious changes in both the width and the intensity of Raman shift peaks. Additional peaks also emerged with $\mathrm{Cr}$ doping. Detailed study has been carried out by Faurel et al. (2003) with similar results. They reported a decrease in the intensity of the modes $<600 \mathrm{~cm}^{-1}$ whereas those at higher wavenumber modes increased. Harmonics and combinations were attributed to be the cause of such evolution $\left(1235=745+490 \mathrm{~cm}^{-1}\right.$, $\left.1490=745 \times 2 \mathrm{~cm}^{-1}\right)$. The influence of chromophore was evidenced by the $735 \mathrm{~cm}^{-1}$ band (Faurel et al. 2003). On the contrary, Lee and Lee (2008a) defined the peak at $1480 \mathrm{~cm}^{-1}$ as that of cassiterite, not malayaite. Given pure oxide generating $\mathrm{Sn}-\mathrm{O}$ stretching at $635 \mathrm{~cm}^{-1}$, the peak in this range is typical of symmetric stretching mode of an octahedron (Faurel et al. 2003). These characteristics are indicative of alterations in bonding nature within the crystal structure, especially when cations were substituted by $\mathrm{Cr}$ ions, increasing disordering toward lattice vibration.

Phase formation was examined by X-ray diffraction (Figure 3). Attempts to calcine the gels at temperatures lower than $1400^{\circ} \mathrm{C}$ did not yield satisfactorily single-phase
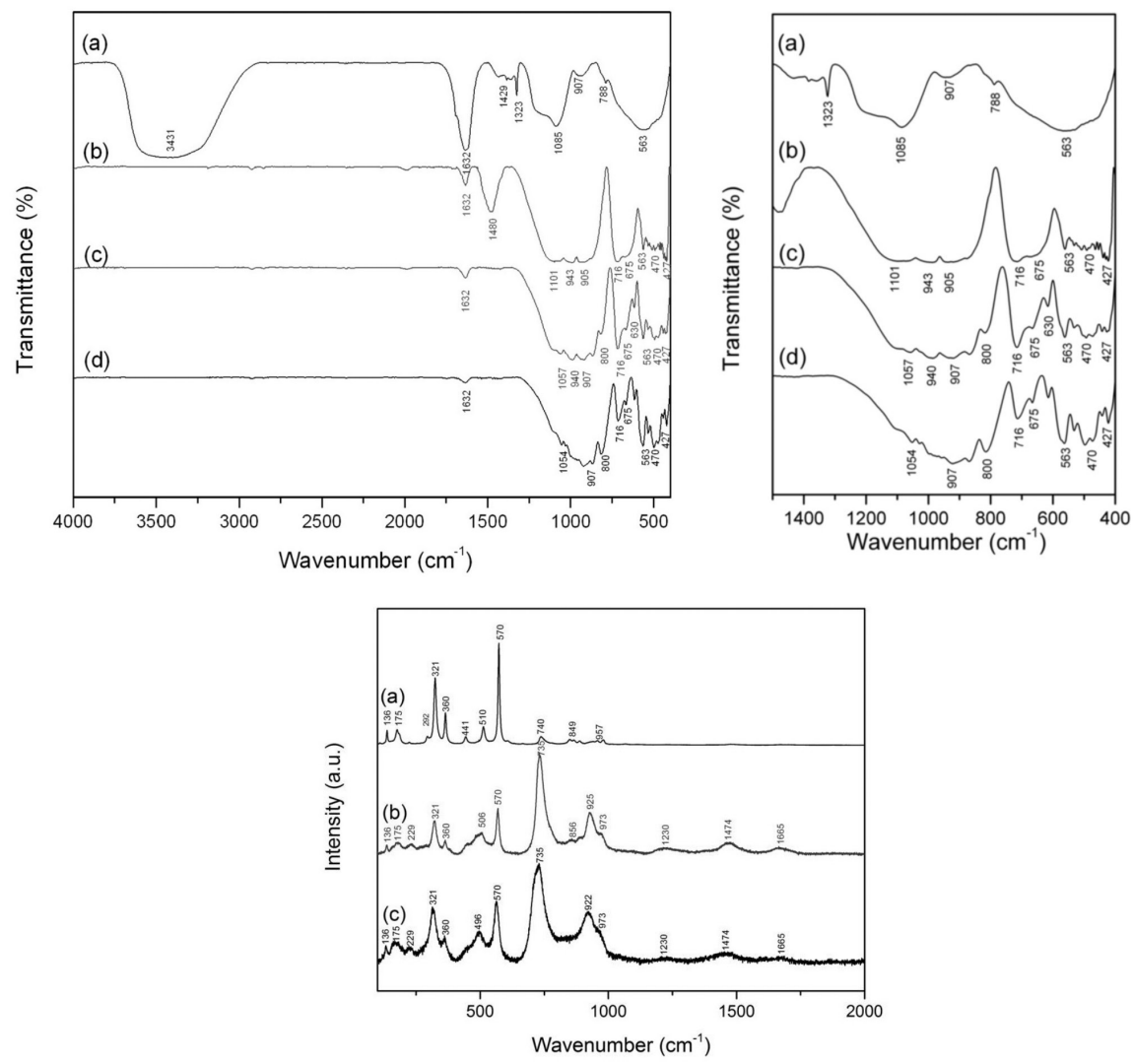

FIGURE 2. Infrared spectra of the samples. The FTIR spectra (upper) are of the $\times=0.05$ samples: (a) uncalcined, (b) $1000^{\circ} \mathrm{C}$, (c) $1200^{\circ} \mathrm{C}$ and (d) $1400^{\circ} \mathrm{C}$. The Raman spectra (lower) are from the samples calcined at $1400^{\circ} \mathrm{C}$ for $24 \mathrm{~h}$ : (a) $\times=0$, (b) $\times=0.02$ and (c) $\times=0.05$ 


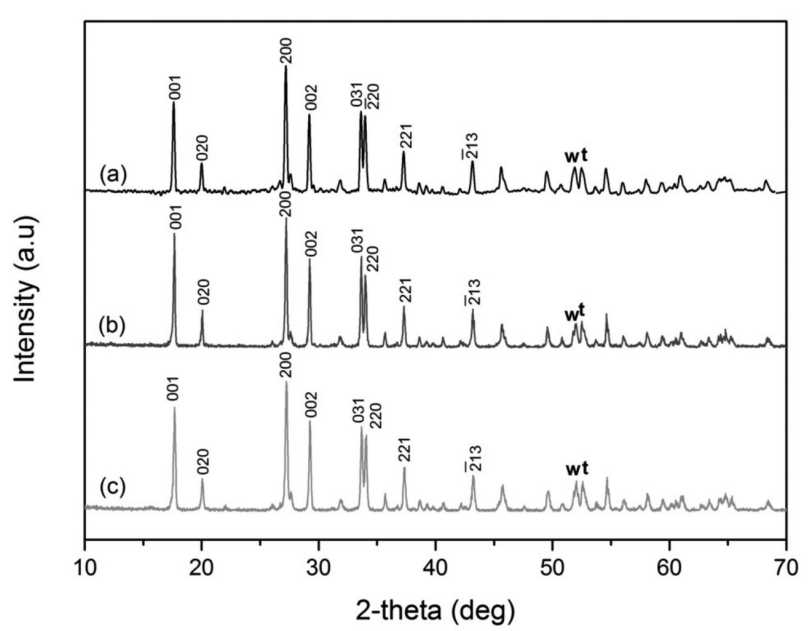

FIGURE 3. XRD patterns of the samples calcined for $3 \mathrm{~h}$ at (a) $1200^{\circ} \mathrm{C}$, (b) $1300^{\circ} \mathrm{C}$ and (c) $1400^{\circ} \mathrm{C}$. The secondary phases $\left(\mathrm{CaSnO}_{3}\right.$ and $\left.\mathrm{SnO}_{2}\right)$ are denoted as ' $\mathrm{w}$ ' and ' $\mathrm{t}$ ', respectively

samples. Difficulty in phase formation has been reported by Pina et al. (2005) and Zhang et al. (2010) of which there still remained a large portion of cassiterite as secondary phase. Malayaite peaks, indexed by JCPDS 25-0176, were observed at $>1000^{\circ} \mathrm{C}$ in agreement with the previous DTA results. Secondary phases still persisted and were found to be wollastonite $\left(\mathrm{CaSiO}_{3}\right)$ and cassiterite $\left(\mathrm{SnO}_{2}\right)$. Since this malayaite phase is composed of several metal-oxide related compounds which by themselves possessed a high degree of refractoriness, long calcining times were required for sufficient diffusion to occur according to Carter's equation. Lee and Lee $(2009,2008$ a) has even reported initiation of formation of malayaite phase at as high as $1200^{\circ} \mathrm{C}$ and $1300^{\circ} \mathrm{C}$. The optimal firing condition in this study was found to be $1400^{\circ} \mathrm{C}$ for $24 \mathrm{~h}$ with intermediate grinding. Long calcination time has been stated to increase crystallinity (Harisanov et al. 2003). Higher firing temperature might result in further sintering of stacked malayaite phase, decreasing the value of $a$ (Zhang et al. (2010). Faurel et al. (2003) stated that the Cr-doped tinbased pink remained stable at $1280^{\circ} \mathrm{C}$ or above whereas Lee et al. (2008a) also reported decomposition of malayaite phase into cassiterite at $1500^{\circ} \mathrm{C}$.

Only slight peak shift was detected possibly due to small different ionic radii between $\mathrm{Sn}^{4+}(\mathrm{CN}-\mathrm{IV} 0.69 \AA$ ) and $\mathrm{Cr}^{4+}(\mathrm{CN}-\mathrm{VI} 0.55 \AA)$ (Shannon 1976). The lattice parameters of the doped $(\mathrm{x}=0.05)$ decreased to $a=7.150 \AA$, $b=$ $8.890 \AA$ and $c=6.670 \AA$ whereas those of the undoped sample were $a=7.160 \AA, b=8.900 \AA$ and $c=6.680 \AA$. In agreement with the study by Lopez-Navarrete et al. (2003), they reported a very small reduction in unit cell volume when $\mathrm{Cr}$ was incorporated at the molar ratio of 0.044 . However, Lee and Lee (2008a) stated the solubility limit to be at $0.02 \mathrm{~mol}$. The authors, through employment of other advanced techniques, proposed that $\mathrm{Cr}^{4+}$ would not fit in the Si tetrahedral lattice $\left(\mathrm{Si}^{4+} \mathrm{CN}-\mathrm{IV} 0.26 \AA\right)$ or in the $\mathrm{Ca}^{2+}$ polyhedron $\left(\mathrm{Ca}^{2+} \mathrm{CN}\right.$-VII $\left.1.06 \AA\right)$. The latter possesses irregular and non-centrosymmetric characters which are undesirable for substitution. Lopez-Navarrete et al. (2003) proposed that the $\mathrm{Cr}^{4+}$ cations could only occupy in the $\mathrm{Sn}^{4+}$ octahedral symmetry. Such substitution might explain the previously shown Raman spectra (Figure 2) in which the intensity of Raman peaks belonging to $\mathrm{Sn}-\mathrm{O}$ reduced significantly upon $\mathrm{Cr}$ doping from $x=0$ to $x=$ 0.05 . This intensity decrease was also coupled with peak broadening, a well-known characteristic of an increased degree of lattice disordering due to occupancy of more than one type of cations. The obtained particles (Figure 4) were found to agglomerate together due to partial sintering with sizes in the $1-5 \mu \mathrm{m}$ range. Comparing to other oxide systems within which doping resulted in an initial increase in crystallite size (Ibrahim 2013), Cr doping did not greatly alter both morphology and size of the obtained particles.

Given the appearance of colour being a directed result from the oxidation state of the chromophore, $\mathrm{X}$-ray photoelectron spectroscopy (XPS) was employed
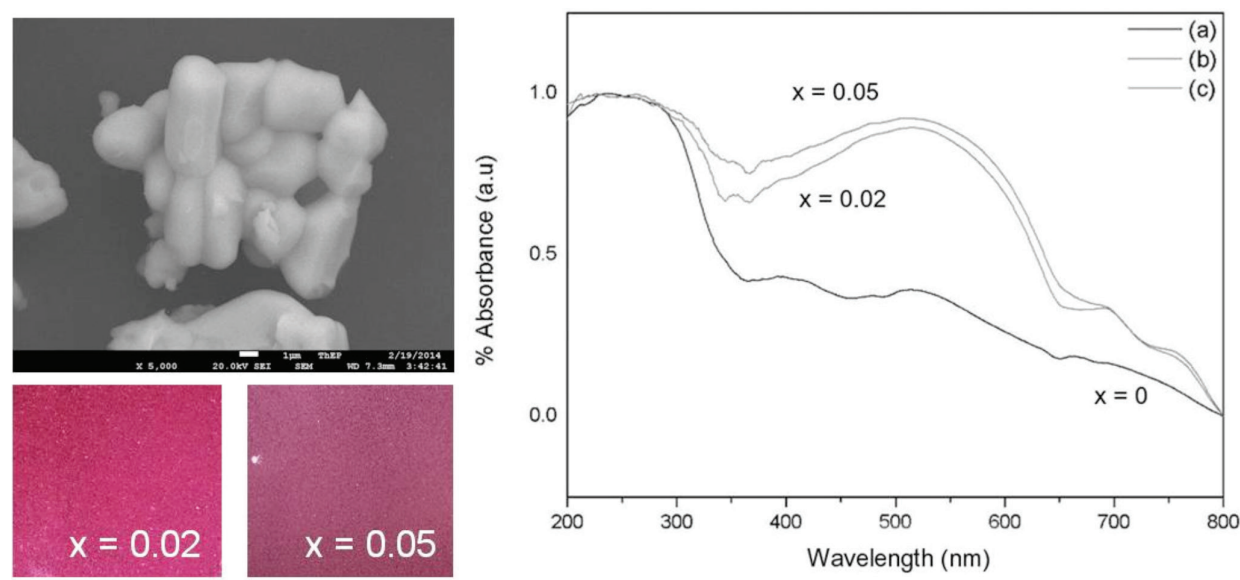

FIGURE 4. Micrograph and optical properties of the pigment samples. The morphology (SEM image) of the typical powders was shown on the left. The UV-vis spectra of both undoped and doped samples are shown on the right with (a) $x=0$, (b) $\times=0.02$ and (c) $x=0.05$ 
to examine certain characteristics of both valence and bonding nature. The XPS spectra are shown in Figure 5 with high resolution of relevant cations; other species (not shown) displayed no anomaly in the peak shape. Given a low amount of $\mathrm{Cr}$ doping, the XPS spectrum of $\mathrm{Cr} 3 \mathrm{p}_{3 / 2}$ was diffused and could not be resolved. Nevertheless, there appears a peak at $576 \mathrm{eV}$ which is in the range of various $\mathrm{Cr}$ oxide compounds reported by Biesinger et al. (2004). With Lorentzian fitting, the shape analysis of corresponding XPS $\operatorname{Sn} 3 \mathrm{~d}_{5 / 2}$ did not display asymmetric shape and yielded a center at $486.3 \mathrm{eV}$, a value very close to those reported in literature (Kwoka et al. 2005). Hence, it is very likely that the $\mathrm{O}-\mathrm{Sn}^{2+}$ bonding was not present in the structure, agreeing with the $\mathrm{Sn}$ octahedron of preferred 4+ valence. The presence of $\mathrm{Cr}^{3+}$ could also be ruled out as LopezNavarrete et al. (2003) has reported that such $\mathrm{Cr}^{3+}$ species, through optical absorption spectra, only occur when calcined in a nitrogen atmosphere. A closer inspection of the $\mathrm{O} 1 \mathrm{~S}$ line revealed no observable asymmetry and no shoulder, highly suggesting no significant asymmetric bonding contribution.

The synthesized pigments displayed colours in the redpurple tone as shown in Figure 6. The colour parameters are displayed in Table 1. The red-purple tone has been attributed to the dissolving of $\mathrm{Cr}^{4+}$ cations in the $\mathrm{Sn}^{4+}$ host lattice by Lopez-Navarrete et al. (2003). A broad, intense peak centered at around $500-550 \mathrm{~nm}\left(18180 \mathrm{~cm}^{-1}\right)$ could be ascribed to the spin allowed ${ }^{3} \mathrm{~T}_{1} \leftrightarrow{ }^{3} \mathrm{~T}_{2}$ transition of octahedral $\mathrm{Cr}^{4+}$ (Lopez-Navarrete et al. 2003). This similar peak was also reported by Lee and Lee (2008a) and Zhang et al. (2010). A drop at around $650 \mathrm{~nm}$ is typical of the $3 \mathrm{~d}^{3}$ ions which are from the anti-crossing of the spin forbidden ${ }^{1} \mathrm{E}$ and ${ }^{1} t_{2}$ levels (Lopez-Navarrete et al. 2003). The absorption band at $380 \mathrm{~nm}$ was originated from unreacted $\mathrm{Cr}^{3+}$ but was not detected by XRD (Lee \& Lee 2009). The brightness $(L)$ decreased by almost half with $\mathrm{Cr}$ doping whereas the positive $a$ value jumped by almost four times, indicating a higher degree of redness. The yellow-blue tone

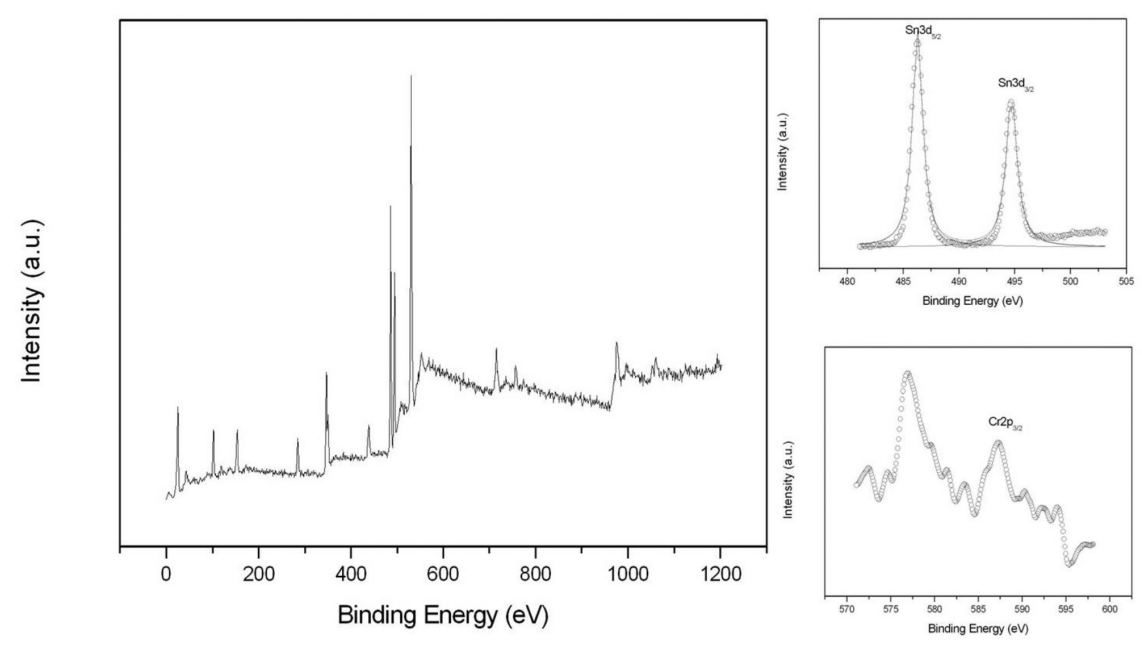

FIGURE 5. XPS spectra of the $x=0.05$ powders calcined at $1400^{\circ} \mathrm{C}$ for $24 \mathrm{~h}$. Other elemental peaks displayed no asymmetric characteristics
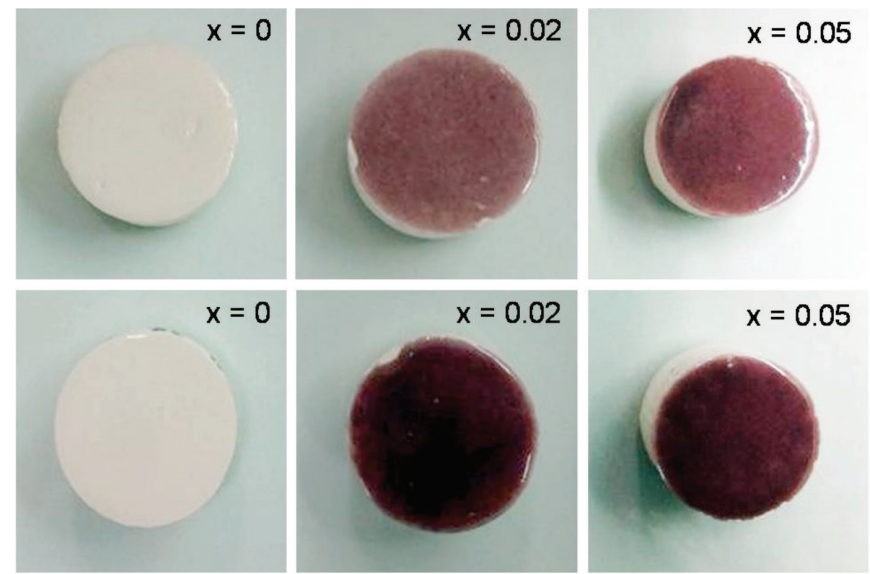

FIGURE 6 . The colours of the glaze mixed with $5 \mathrm{wt} . \%$ pigments of different compositions. The glazes were fired at $900^{\circ} \mathrm{C}$ (upper) and $1000^{\circ} \mathrm{C}$ (lower) 
TABLE 1. Colour parameters of the pigment powders calcined at $1400^{\circ} \mathrm{C}$ for $24 \mathrm{~h}$.

$\Delta \mathrm{E}$ values were included for comparison purpose

\begin{tabular}{ccccc}
\hline \multirow{2}{*}{ Composition } & \multicolumn{4}{c}{ Colour parameter } \\
\cline { 2 - 5 } & $\mathrm{L}^{*}$ & $\mathrm{a}^{*}$ & $\mathrm{~b}^{*}$ & $\Delta \mathrm{E}$ \\
\hline $\mathrm{x}=0.00$ & $89.4 \pm 0.1$ & $3.4 \pm 0.2$ & $2.0 \pm 0.0$ & - \\
$\mathrm{x}=0.02$ & $49.1 \pm 0.3$ & $13.5 \pm 0.1$ & $1.1 \pm 0.0$ & $41.6 \pm 0.22$ \\
$\mathrm{x}=0.05$ & $45.8 \pm 0.4$ & $12.2 \pm 0.1$ & $1.9 \pm 0.1$ & $3.6 \pm 0.14$ \\
\hline
\end{tabular}

TABLE 2. Colour parameters of the glazes with $5 \mathrm{wt}$. \% pigments. The glazes were fired at different temperatures and appeared to mature at $\geq 900^{\circ} \mathrm{C}$. $\Delta \mathrm{E}$ values were included for comparison purpose

\begin{tabular}{|c|c|c|c|c|c|}
\hline \multirow[t]{2}{*}{ Composition } & \multirow{2}{*}{$\begin{array}{l}\text { Calcining } \\
\text { temperature }\end{array}$} & \multicolumn{4}{|c|}{ Colour parameter } \\
\hline & & $\mathrm{L}^{*}$ & $a^{*}$ & $\mathrm{~b}^{*}$ & $\Delta \mathrm{E}$ \\
\hline \multirow[t]{3}{*}{$x=0.00$} & 900 & $86.6 \pm 0.3$ & $4.9 \pm 0.3$ & $8.0 \pm 0.2$ & - \\
\hline & 950 & $87.4 \pm 0.1$ & $4.7 \pm 0.1$ & $8.5 \pm 0.0$ & - \\
\hline & 1000 & $87.3 \pm 0.7$ & $4.7 \pm 0.1$ & $8.6 \pm 0.2$ & - \\
\hline \multirow[t]{3}{*}{$x=0.02$} & 900 & $48.4 \pm 0.5$ & $19.1 \pm 0.8$ & $1.3 \pm 0.1$ & $41.3 \pm 0.54$ \\
\hline & 950 & $47.5 \pm 0.5$ & $20.2 \pm 0.3$ & $2.3 \pm 0.2$ & $43.2 \pm 0.48$ \\
\hline & 1000 & $39.5 \pm 0.5$ & $20.3 \pm 0.4$ & $2.7 \pm 0.1$ & $50.6 \pm 0.37$ \\
\hline \multirow[t]{3}{*}{$x=0.05$} & 900 & $43.6 \pm 0.0$ & $14.7 \pm 1.4$ & $1.1 \pm 0.5$ & $6.5 \pm 0.76$ \\
\hline & 950 & $39.7 \pm 1.4$ & $15.7 \pm 1.2$ & $2.0 \pm 0.8$ & $9.0 \pm 1.40$ \\
\hline & 1000 & $34.2 \pm 1.2$ & $14.4 \pm 0.4$ & $2.4 \pm 0.2$ & $7.9 \pm 0.71$ \\
\hline
\end{tabular}

(b) remained relatively unchanged. It is important to keep in mind that the appeared colour could be caused by $\mathrm{Cr}$ doping in both malayaite and cassiterite as suggested by Lee and Lee (2008b). Nevertheless, from the XRD patterns (Figure 3), the $\mathrm{SnO}_{2}$ peaks were only minor compared to major malayaite. The UV-vis absorption was found to peak at around $500 \mathrm{~nm}$, corresponding to the visible colour in the red tone as previously reflected by the value of $a$ parameter (CIELab system) in the 10-15 range. Increasing amount of $\mathrm{Cr}$ doping to $x=0.05$ resulted in a small decrease in the $a$ value which is similar to those reported by Lopez-Navarrete et al. (2002).

Technological performance was done by the test with a low-fire glaze (borosilicate frit) and the colour values are shown in Table 2. The resultant colour was still in the reddish tone with the value of $a$ parameter (CIELab system) increasing up to 20 for the $x=0.02$ pigment powders. The greenish tint was not evidenced much (judged from a low value of b), possibly pointing to a certain degree of chromophore's structural stability embedded in the host matrix of malayaite. It is very interesting to point out a sharp increase in the $a$ parameter, which might be caused by specific intereaction between certain components in the raw glaze and the pigments. It is believed that some $\mathrm{Cr}$ ions might diffuse out and interact with unreacted cassiterite, yielding the red tone. All these colour parameter data from the sol-gel processed pigments exhibited superior performance compared to those fabricated by solid-state processing. With similar processing parameters, the solid-state pigments yielded a slightly lower degree of redness when incorporating in the glaze.

\section{CONCLUSION}

Sol-gel synthesis of $\left(\mathrm{Cr}_{\mathrm{x}}\right)\left(\mathrm{CaSnSiO}_{5}\right)_{1-\mathrm{x}}$ malayaite colour pigment has been shown to yield a relatively more superior colour characteristics in low-fire glaze compared with those produced by solid-state reaction. Moreover, single phase could be readily obtained possibly due to high reactivity of intermediate compounds formed during solgel processing but a slight XRD peak shift toward higher angles could be observed. The XPS study suggested no significant asymmetric bonding character, likely resulting from substitution of closely similar ionic radii between $\mathrm{Sn}^{4+}$ and $\mathrm{Cr}^{4+}$. Such substitution could also be indirectly inferred from Raman spectra with lowered intensity and peak broadening belonging to $\mathrm{Sn}-\mathrm{O}$ vibration. The synthesized pigment powders possessed positive value of $a$ colour parameter, appearing toward the red tone. The pigment-containing glazes still exhibited sufficiently strong red to purple tone which could be of great interest in the ceramic industry.

\section{ACKNOWLEDGEMENTS}

This study was financially supported by the Higher Education Research Promotion (HERP), Office of the Higher Education Commission, budget year 2015 (2558). The grant number is SURDI 58/01/08 with a title of 'Development of pink-tone malayaite colour pigment nanopowders for tile glaze in construction industry'.

\section{REFERENCES}

Biesinger, M.C., Brown, C., Mycroft, J.R., Davidson, R.D. \& McIntyre, N.S. 2004. X-ray photoelectron spectroscopy 
studies of chromium compounds. Surface and Interface Analysis 36: 1550-1563.

Faurel, X., Vanderperre, A. \& Colomban, P. 2003. Pink pigment optimization by resonance Raman spectroscopy. Journal of Raman Spectroscopy 34: 290-294.

Halefoglua, Y.Z. \& Kusvuran, E. 2010. Preparation of ceramic pigments by sol-gel and combustion methods. Journal of Ceramic Processing Research 11(1): 92-95.

Harisanov, V., Pavlov, R.S., Marinova, I.T., Kozhukharov, V. \& Carda, J.B. 2003. Influence of crystallinity on chromatic parameters of enamels coloured with malayaite pink pigments. Journal of the European Ceramic Society 23: 429-435.

Ibrahim, N.B., Baqiah, H. \& Abdullah, M.H. 2013. High transparency iron doped indium oxide $\left(\mathrm{In}_{2-\mathrm{x}} \mathrm{Fe}_{\mathrm{x}} \mathrm{O}_{3}, \mathrm{x}=0.0\right.$, $0.05,0.25,0.35$ and 0.45$)$ films prepared by the sol-gel method. Sains Malaysiana 42(7): 961-966.

Kwoka, M., Ottaviano, L., Passacantando, M., Santucci, S., Czempik, G. \& Szuber, J. 2005. XPS study of the surface chemistry of L-CVD $\mathrm{SnO}_{2}$ thin films after oxidation. Thin Solid Films 490: 36-42.

Lee, H.S. \& Lee, B.H. 2008a. Colouring effect of malayaite formation and synthesis sphene-pink pigment. Journal of Korean Ceramic Society 45(3): 172-178.

Lee, H.S. \& Lee, B.H. 2008b. The development of a chromium pink glaze coloring. Journal of Ceramic Processing Research 9(3): 286-291.

Lee, H.S. \& Lee, B.H. 2009. Synthesis of sphene $\left(\mathrm{CaSnSiO}_{5}\right)-$ pink pigments with $\mathrm{CrCl}_{3}$. Journal of Korean Ceramic Society 46(4): 405-412.

Lopez-Navarrete, E. \& Ocaña, M. 2002. A simple procedure for the preparation of $\mathrm{Cr}$-doped tin sphene pigments in the absence of fluxes. Journal of the European Ceramic Society 22: 353-359.
Lopez-Navarrete, E., Caballero, A., Orera, V.M., Lazaro, F.J. \& Ocana, M. 2003. Oxidation state and localization of chromium ions in Cr-doped cassiterite and Cr-doped malayaite. Acta Materialia 51: 2371-2381.

Ou-benmmou, I., Ahamdane, H., El idrissi Raghni, M.A., Bensamka, F., Mosset, A., El Idrissi Moubtasim, M.L. \& Jumas, J.C. 2000. Tin sphene micron-sized powders. Journal of the European Ceramic Society 20: 2159-2163

Piña, C., Arriola, H. \& Nava, N. 2005. Study of malayaite and malayaite cobalt pigment. Hyperfine Interaction 161: 93-97.

Shannon, R.D. 1976. Revised effective ionic radii and systematic studies of interatomic distances in halides and chalcogenides. Acta Crystallographica A32: 751-767.

Zhang, L., Pi, Z., Yang, C., Tian, X. \& Zhang, S. 2010. Synthesis of chromium-doped malayaite pigments from wastewater containing low chromium(VI). Journal of the Air and Waste Management Association 60: 1257-1261.

Department of Materials Science and Engineering

Silpakorn University

Thailand

*Corresponding author; email: niti.yongvanich@gmail.com

Received: 30 August 2016

Accepted: 13 October 2017 